\title{
Study of the Floristic Composition of Certain Secondary Grasslands in Different Successional Stages as a Result of Abandonment
}

\author{
Florin PĂCURAR*, Ioan ROTAR, Anca PLEŞA, Ágnes BALÁZSI, Roxana VIDICAN \\ ${ }^{1}$ Faculty of Agriculture, University of Agricultural Sciences and Veterinary Medicine, \\ Mănăștur Street nr. 3-5, 400372, Cluj-Napoca, Romania; \\ * corresponding author: fpacurar@gmail.com \\ Bulletin USAMV series Agriculture 72(1)/2015 \\ Print ISSN 1843-5246; Electronic ISSN 1843-5386 \\ DOI 10.15835/buasvmcn-agr: 11165
}

\begin{abstract}
Important areas of semi-natural grasslands are affected by abandonment in Apuseni Mountains, situation that leads to a series of specific negative aspects. Semi-natural grasslands pass through certain successional stages, materialized by different types of grasslands. The aim of our study was to follow the successional stages of Agrostis capillaris L. - Festuca rubra L. grassland type, as a result of abandonment. The study included 27 grasslands with similar site conditions. There were three different categories of abandoned grasslands: abandoned up to 5 years, abandoned between 6 and 10 years, abandoned more than 10 years. The categories of abandonment caused changes at the level of phytocoenoses, registering a degradation of the vegetation from both, agronomic and ecologic point of view. The semi-natural grasslands, situated on sites with different disadvantages (defectuous orography, reduced trophicity, pronounced acidity, etc.) which are on the threshold to be abandoned, or are already abandoned, need to be mowed at least once at four or five years, to preserve their specific floristic structure.
\end{abstract}

Keywords: abandonment, agronomic value, phytodiversity, semi-natural grasslands.

\section{INTRODUCTION}

The abandonment of semi-natural grasslands in the mountain areas become a major threat and raises a series of questions and situations, which have to be solved in the whole Europe (Osterburg et al., 2010). Grasslands in the mountain areas are very vulnerable habitats, losing their conservation value very quickly after the abandonment (Fischer and Wipf, 2002). In these areas secondary succession takes place, which could be found in the first stage as changes in specific floristic composition of the canopy (Habel et al., 2013). Changes can be sometimes so obvious, that threaten the integrity of the grassland ecosystem (Kryszak et al., 2012). Restoration of the grassland ecosystem to the original stage could be a very long process and almost impossible (Galvanek and
Leps, 2012). Romania's pastoral area is covering over 4.8 million ha and has been influenced over the last decades by natural factors and human activities, which have been affected the normal functioning of the grassland ecosystems (Vîntu et al., 2011). From these grasslands, more than a half are located in upland areas (Vîntu et al., 2011). In addition, the secondary grasslands from Apuseni Mountains and their high diversity are endangered by the land use's changes, caused by the direct and indirect influence of socio economic changes (Gârda, 2011). Even if the phenomenon in general is well known in other European countries, is needed a thorough understanding of the mechanisms, which occur at the phytocoenoses level because of the abandonment (Kahmen et al., 
2002; Bilz et al., 2011; Habel et al., 2013; Halada et al., 2011; Socher et al., 2013).

The aim of our study was to follow the successional stages of Agrostis capillaris L. Festuca rubra L. grassland type, as a result of abandonment.

\section{MATERIALS AND METHODS}

The study included the floristic composition's determination of certain secondary grasslands in different successional stages as a result of abandonment. The plots were chosen so they have about the same site conditions. The length of plots' abandonment was divided in three categories, as follows: abandoned grasslands up to 5 years (F1), abandoned grasslands between 6 and 10 years (F2), abandoned grasslands more than 10 years (F3). The length of abandonment was determined by questionnaires applied to the owners. Also, the length of abandonment was assessed following the age of the present woody species. The floristic composition was determined by Bran-Blanquet method, when Poaceae were in flower. Floristic data processing was performed with PC-ORD, version 6, which use the multivariate analysis of the ecological data entered into the spreadsheet. This program focuses on nonparametric tools, on graphics, randomization tests, bootstrapped confidence intervals for analysis of community data (McCune and Grace, 2011). For data processing and interpretation we used multidimensional scaling (NMS), which is well suited to data coordination that are not normal or stairs arbitrary, discontinuous, or otherwise questionable (Peck, 2010). Also, we used the MRPP (Multi Response Permutation Procedure) and Summary for the ShannonWiener index $(\mathrm{H})$ and the number of species $(\mathrm{S})$ and the average abundance and dominance of the species. Based on the Shannon-Wiener index and the number of species, we compared the diversity of different abandonment categories. To evaluate the effects of abandonment on vegetation, from statistical point of view, we used STATISTICA by StatSoft. The analysis of variance was performed by Breakdown and One-Way ANOVA type. Based on $\mathrm{F}$ and $\mathrm{p}$ values was determined species on which, the different abandonment categories had the highest effect, using the average abundancedominance of the species. To analyze in detail the effect of abandonment we used a comparative analysis, Post-hoc, the Fisher LSD type. The choice of this test was based on the ability to highlight significant differences between the categories of abandonment and between the average abundance-dominance of dominant species, economic groups of plants and phytodiversity.

\section{RESULTS AND DISCUSSIONS}

The statistical analysis of the data highlighted that floristic composition can be separated in three different grassland types (Fig.1).

The phytocoenosis of abandoned grasslands up to 5 years (F1) is very different from the other categories of abandoned grasslands $(\mathrm{T}=$ $-6,7861, \mathrm{p}<0.001$ and $\mathrm{T}=-6,5185, \mathrm{p}<0.001$; Tab. $1)$. The analysed groups are quite heterogeneous $(A=0.1218$ and $A=0,1431)$. The phytocoenosis of abandoned grasslands between 6 and 10 years (F2) is different than the phytocoenosis of grasslands abandoned more than 10 years (F3), but this two are still overlapped, when are graphically presented $(\mathrm{T}=-4.9935, \mathrm{p}<0.001$; fig. 1, Tab. 1).

Abandoned grasslands' phytocoenoses up to 5 years (F1) take part from Agrostis capillaris L. - Festuca rubra L. grassland type, which has in floristic composition $41.07 \%$ of Poaceae, $14.11 \%$ of Fabaceae, $0.14 \%$ of Cyperaceae and Juncaceae and $41.79 \%$ plants from other botanical families (Tab.2). The phytodiversity of these phytocoenoses have 31.71 species and a Shannon-Wiener index of 2.30. The phytocoenoses of abandoned grasslands between 6 and 10 years (F2) belong to Festuca rubra L. type with $18.62 \%$ of Poaceae, $3.94 \%$ Fabaceae, $1.11 \%$ of Cyperaceae and Juncaceae and $54.58 \%$ of plants from other botanical families. This phytocoenosis consists from 25.44 species and has a Shannon-Wiener index of 2.30. The abandoned grasslands more than 10 years (F3) belongs to Nardus stricta L. types and the floristic composition is composed from $33.09 \%$ of Poaceae, 2.95\% of Fabaceae, 5.73\% of Cyperaceae and Juncaceae and $43.39 \%$ of plants from other botanical families. The phytodiversity covers 23.09 species and the Shannon-Wiener index is 2.10. Kącki (2010) evidenced in a study, in the southeastern part of Poland, the fact that Nardus stricta L. occurs in abandoned grasslands with a high percentage at the expense of medium and high tolerant species on mowing. Mariott et al. (2004) in an experiment in 20 European countries 
show that the abandonment of grassland ecosystems causes important changes in the canopy's structure in comparison to the mowed or pastured areas. Changes in the canopy, in their experiment, occurred after different time intervals from an experiment to other. Some changes could be observed after two years, others only after 12 years. They also state that changes strongly depend on site conditions, on original vegetation, on management's history and on vegetation in around.

From agronomic point of view, the phytocoenosis, because of the abandonment, degrades through installation of some less productive and lower quality grassland types. This degradation can be seen by the reduction of Agrostis capillaris L. from $21.39 \%$ (F1) to $1.47 \%$ in the case of abandoned grasslands between 6 and 10 years (F2) and to $1.95 \%$ in the case of abandoned grasslands more than 10 years (F3; $p<0.001$; Tab.1). Also, there is a reduction at Festuca rubra L. species too, especially for grasslands abandoned more than 10 years (F3), but without statistical assurance ( $p>0.05)$. Grassland's degradation is highlighted by the increase of Nardus stricta L. cover, from $1.94 \%$ to $21.36 \%$ ( $<<0.01)$, which is a species without forage value.

When pursuing the floristic composition's evolution at the economic groups level, we can find the same canopy degradation, by decreasing the cover of Poaceae $(p<0.01)$, reduction of the level of Fabaceae ( $p<0.001$; Tab.1). Plants from

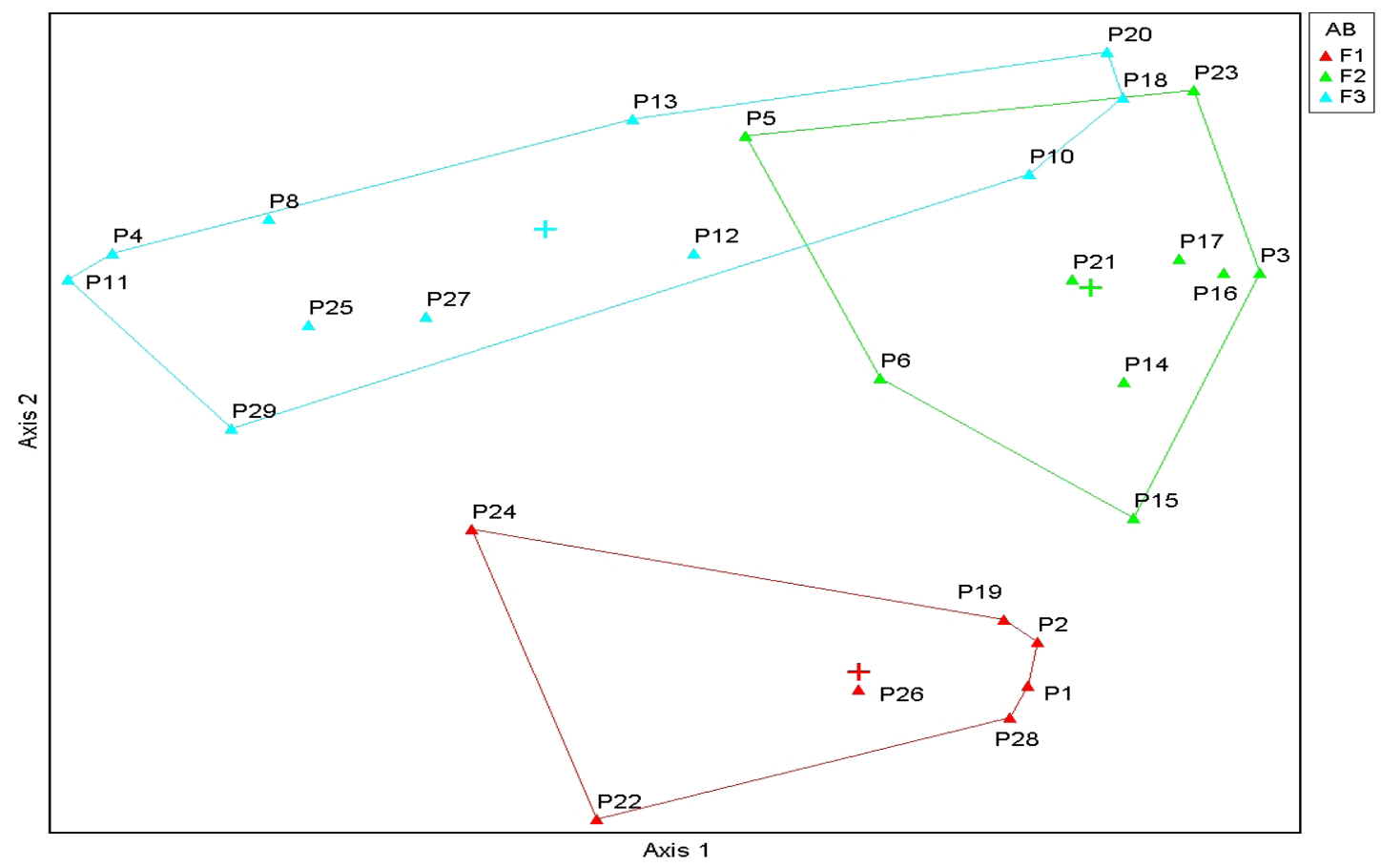

Fig. 1. Ordination of floristic composition in function of different abandonment categories; P - relevees, $\mathrm{F}_{1}$ - abandoned grassland up to 5 years, $\mathrm{F}_{2}$ - abandoned grassland between 6 and 10 years, $\mathrm{F}_{3}$ abandoned grassland more than 10 years

Tab. 1. Comparison between the floristic compositions of different abandonment categories with MRPP

\begin{tabular}{cccc}
\hline Comparison between variants & T & A & p \\
\hline F1 vs. F2 & -6.786198 & 0.121860 & 0.000044 \\
\hline F1 vs. F3 & -6.518563 & 0.143136 & 0.000229 \\
\hline F2 vs. F3 & -4.993546 & 0.098741 & 0.002312 \\
\hline Note: T - T test, A - group homogeneity, p - statistical significance & &
\end{tabular}


other botanical families increase slightly, but there is no statistically assurance for their evolution.

Da Ronch et al. (2013) show in a study, carried out in valleys of Val Menera (north-eastern Italy), that abandonment of mountain pastures resulted a significant reduction of agronomic value and forage digestibility, due to a strong installation of Deschampsia caespitosa L. species in the canopy. From conservative point of view, we find also a degradation at the grassland vegetation level, because the number of species is reduced in the case of abandoned grasslands up to 5 years (F1) from 31.71 to 23.09 at the abandoned grasslands up to 10 years (F3; p<0.01; Tab.1). The ShannonWiener index shows a decrease of phytodiversity from 2.30 (F1) to 2.10 (F3), but without statistically assurance. In the studies of Zarzycki and Misztal (2010), the abandoned plots had a significantly lower Shannon-Wiener index than it was in the mowed plots. Musiał and Kasperczyk (2013) have the same results with ours in the Polish Carpathians, where the abandonment of permanent grasslands between $600 \mathrm{~m}$ and $700 \mathrm{~m}$ caused a significant reduction of the phytodiversity. Da Ronch et al. (2010) shows in a study carried out in Treviso (Italia), that abandonment changed significantly the phytodiversity after 12 years, but mowing once per year reduced the woody species participation. Kacki (2010) has shown that for grasslands species, diversity index values were significantly higher on permanently managed grasslands, than on abandoned pastures at least since 5 years. Schrautzer et al. (2010) demonstrate that on abandoned grasslands for 9 years, in the region Schleswig-Holstein (Germany) and grazed later with cattle in an extensive system, the phytodiversity increased considerably.

In Agrostis capillaris L.- Festuca rubra L. grassland type the most abundant species in addition to dominant species are: Centaurea pseudophrygia C. A. Mey, Cirsum palustre L., Trifolium pratense L., Trifolium repens L., Nardus stricta L., Leontodon autumnalis L., Plantago media L., Lotus corniculatus L., Alchemilla vulgaris L., Thymus pulegiodes L., etc. The least dominant species are: Silene vulgaris Moench, Deschampsia flexuosa L., Verbascum phlomoides L., Anthyllis vulneraria L., Veratrum album L., Trollius europeaeus L., Luzula campestris L., etc. (Fig. 2).

The most frequent species are: Leontodon autumnalis L., Centaurea pseudophrygia C. A. Mey, Lotus corniculatus L., Scabiosa columbaria L., Campanula patula L., Leucanthemum vulgare Lam., Thymus pulegiodes L., Potentilla erecta L., Carlina acaulis L., Pimpinella major L., etc. The least frequent species are: Galium verum L., Deschampsia flexuosa L., Veratrum album L., Trifolium pratense L., Luzula campestris L., Hieracium aurantiacum L. (Fig. 3).

In Festuca rubra L. grassland type the most abundant species in addition to dominant species are: Leontodon autumnalis L., Thymus pulegiodes L., Plantago media L., Alchemilla vulgaris L., Sanguisorba minor Scop., Hieracium aurantiacum

Tab. 2. Floristic structure of grassland types in function of abandonment's categories

\begin{tabular}{|c|c|c|c|c|c|c|c|c|c|c|}
\hline \multirow{2}{*}{\multicolumn{2}{|c|}{$\begin{array}{c}\text { Treatments/Significance/ } \\
\text { Grassland type }\end{array}$}} & \multicolumn{3}{|c|}{$\begin{array}{c}\text { Dominant and } \\
\text { codominant species }\end{array}$} & \multicolumn{4}{|c|}{ Economic groups } & \multicolumn{2}{|c|}{ Phytodiversity } \\
\hline & & A.C & F.r. & N.S. & $P$ & $F$ & $C L$ & $O B F$ & $S$ & H \\
\hline $\begin{array}{l}\mathrm{F}_{1} \text { - abandoned grasslands } \\
\text { up to } 5 \text { years }\end{array}$ & \multirow{2}{*}{$\begin{array}{l}\text { A.c.- } \\
\text { F.r. }\end{array}$} & 21.39 & 11.01 & 4.64 & 41.07 & 14.11 & 0.14 & 41.79 & 31.71 & 2.30 \\
\hline Sgf. & & Wt. & Wt. & Wt. & Wt. & Wt. & Wt. & Wt. & Wt. & Wt. \\
\hline $\begin{array}{l}F_{2} \text { - abandoned grasslands } \\
\text { between } 6 \text { and } 10 \text { years }\end{array}$ & \multirow{2}{*}{ F.r. } & 1.47 & 12.53 & 1.94 & 18.62 & 3.94 & 1.11 & 54.58 & 25.44 & 2.30 \\
\hline Sgf. & & 000 & ns & ns & 00 & 000 & ns & Us & 0 & ns \\
\hline $\begin{array}{l}\mathrm{F}_{3}-\text { abandoned grasslands } \\
\text { more than } 10 \text { years }\end{array}$ & \multirow{2}{*}{ N.s. } & 1.95 & 4.93 & 21.36 & 33.09 & 2.95 & 5.73 & 43.39 & 23.09 & 2.10 \\
\hline Sgf. & & 000 & ns & $* *$ & ns & 000 & ns & ns & 00 & ns \\
\hline
\end{tabular}

Note: A.c. = Agrostis capillaris L., F.r. = Festuca rubra L., N.s. = Nardus stricta L., $\mathrm{P}=$ Poaceae, $\mathrm{F}=$ Fabaceae, $\mathrm{CJ}=$ Cyperaceae and Juncaceae, $\mathrm{OBF}$ = Other botanical families, $\mathrm{T}=$ Treatments, Sgf. $=$ Significance, $\mathrm{H}=$ Shannon-Wiener index, $\mathrm{S}=$ Species number, A.c.-F.r. $=$ Agrostis capillaris L. Festuca rubra L., Wt. $=$ witness, ${ }^{*}=p<0.05,{ }^{* *}=p<0.01,{ }^{* * *}=p<0.001 ; 0=p<0.05,00=p<0.01,000=p<0.001$, ns - not significant. 


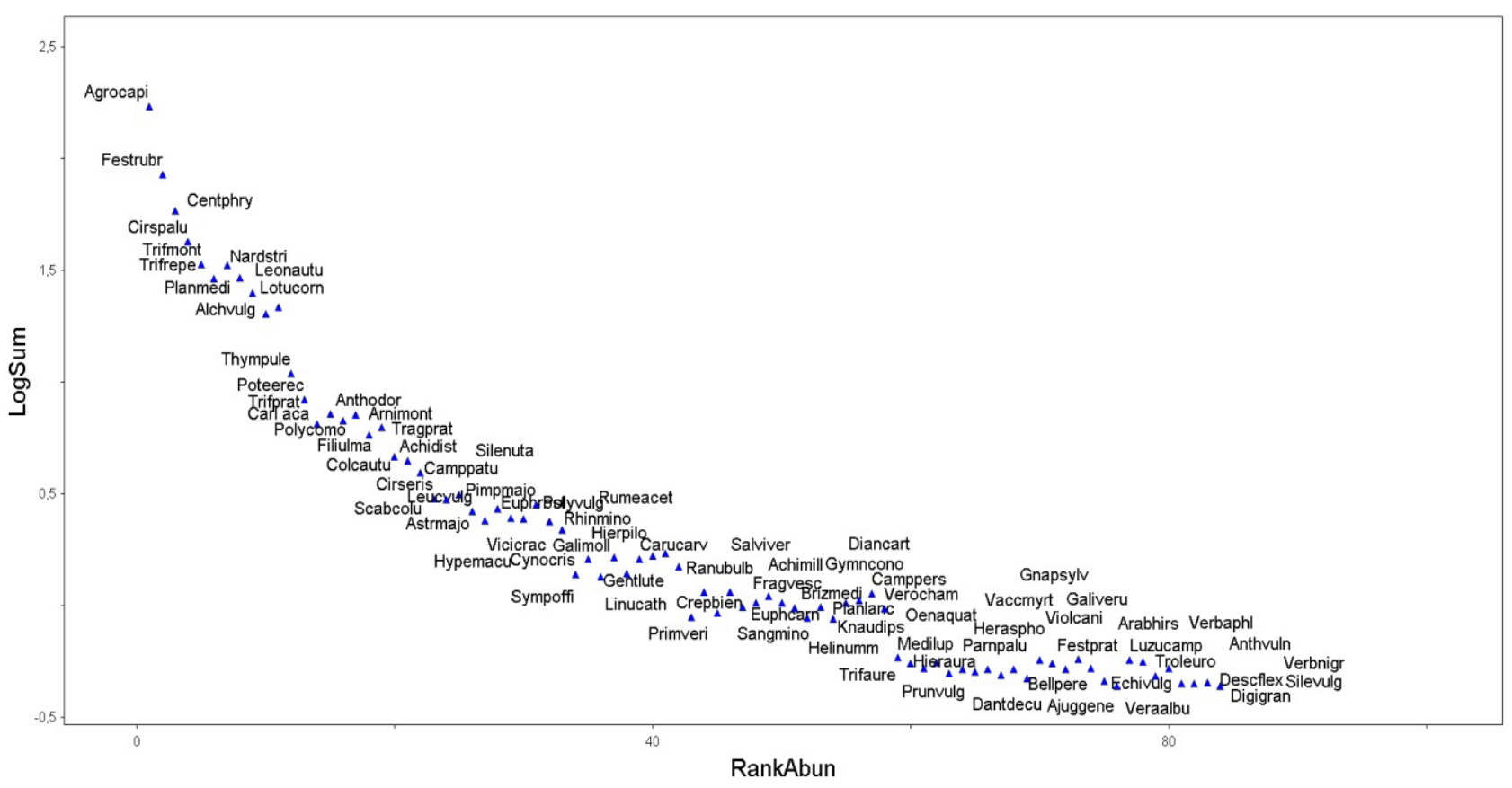

Fig. 2. Abundance of species in the phytocoenosis of Agrostis capillaris L.-Festuca rubra L. grassland type (Rankabund = Species abundance, Logsum= Logarithm with base 10 of species abundance; Achimill = Achillea millefolium L.; Agrocapi = Agrostis capillaris L.; Alchvulg = Alchemilla vulgaris L.; Antedioi = Antenaria dioica L.; Anthodor = Anthoxanthum odoratum L.; Anthvuln = Anthyllis vulneraria L.; Arnimont = Arnica montana L.; Arabhirs = Arabis hirsuta L.; Ajuggene=Ajuga genevensis L.; Brizmedi = Briza media L.; Campabie = Campanula abietina Griseb.; Camppatu = Campanula patula L.; Cardhale $=$ Cardaminopsis halleri L.; Carepall $=$ Carex pallescens $\mathrm{L}$; Carlacau $=$ Carlina acaulis L.; Centmoll = Centaurea mollis Waldst. et Kit.; Centpseu = Centaurea pseudophrygia C. A. Mey.; Colcautu = Colchicum autumnale L.; Crepbien = Crepis biennis L.; Cerahole = Cerastium holesteoides Fr.em. Hyl.; Cynocris = Cynosurus cristatus L.; Descflex = Deschampsia flexuosa L.; Eryncamp = Eryngium campestre L.; Euphrosko = Eupharsia roskoviana Hayne; Festprat $=$ Festuca pratensis L., Festrubr = Festuca rubra L.; Galiveru = Galium verum L.; Gnafsylv = Gnafalium sylvaticum L.; Gymncono = Gymnadenia conopsea L.; Hieraura = Hieracium aurantiacum L.; Hypemacu = Hypericum maculatum Crantz; Leonautu = Leontodon autumnalis L.; Leucvulg = Leucanthemum vulgare Lam.; Lotucorn = Lotus corniculatus L.; Luzucamp = Luzula campestris L.; Luzumult = Luzula multiflora Ehrh.; Nardstri = Nardus stricta L.; Pimpmajo = Pimpinella major L.; Planlanc $=$ Plantago lanceolata L.; Planmedi $=$ Plantago media L.; Polycomo = Polygala comosa Schkuhr.; Polyvulg = Polygala vulgaris L.; Poteerec = Potentilla erecta L.; Prunvulg = Prunella vulgaris L.; Ranuacri = Ranunculus acris L.; Ranubulb = Ranunculus bulbosus L.; Rhinmino = Rhinanthus minor L.; Rumeacet $=$ Rumex acetosa L.; Salvvert $=$ Salvia verticilata L.; Sangmino= Sanguisorba minor Scop.; Scabcolu = Scabiosa columbaria L.; Scorrose = Scorzonera rosea Waldst. et Kit; Silevulg = Silene vulgaris Moench; Stelgram = Stellaria graminea L.; Taraoffi = Taraxacum officinale Weber ex F.H.Wigg.; Thympule = Thymus pulegiodes L.; Tragprat = Tragopogon pratensis L.; Trifprat $=$ Trifolium pratense L.; Trifrepe $=$ Trifolium repens L.; Trisflav $=$

Trisetum flavescens L.; Troleuro = Trollius europeaeus L.; Verocham = Veronica chamaedrys L., Veraalbu = Veratrum album L.; Vicicrac = Vicia cracca L., Violcani = Viola canina L.; Violtric $=$ Viola tricolor L.) 
L., Nardus stricta L., Arnica montana L., Carlina acaulis L., Lotus corniculatus L., Agrostis capillaris L., etc. The least dominant are: Rumex acetosa L., Ranunculus bulbosus L., Gymnadenia conopsea L; Rhinanthus minor L., Taraxacum officinale
Weber ex F.H.Wigg, Trifolium pratense L., Luzula campestris L., Vicia cracca L., etc. (Fig. 4).

The most frequent species are: Thymus pulegiodes L., Plantago media L., Leontodon autumnalis L., Alchemilla vulgaris L., Carlina acaulis

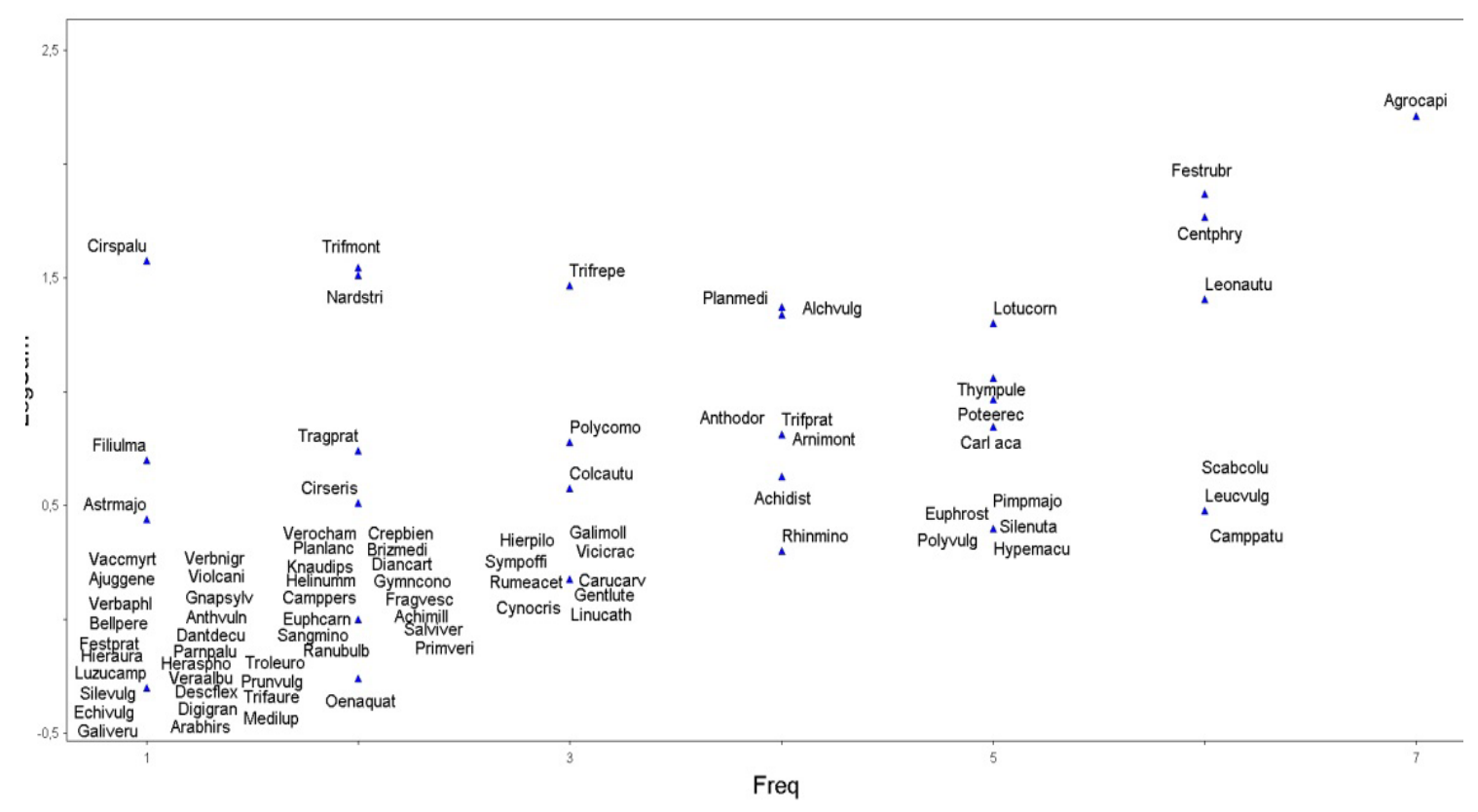

Fig. 3. Frequency of species in the phytocoenosis of Agrostis capillaris L.-Festuca rubra L. grassland type; Freq = Species frequency; Logsum = Logarithm with base 10 of species abundance; for species name abbreviation see the legend of Fig.2

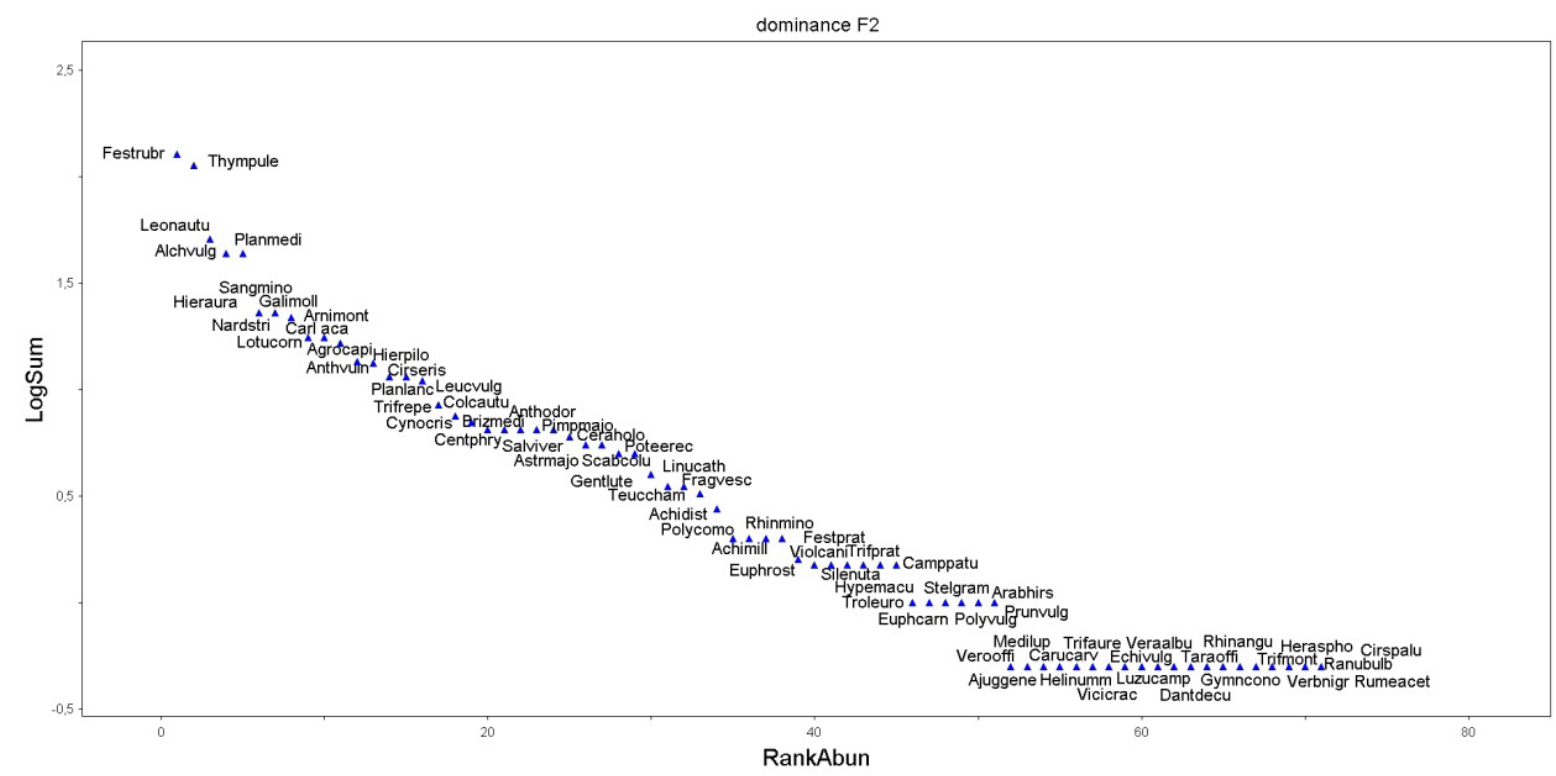

Fig. 4. Abundance of species in the phytocoenosis of Festuca rubra L. grassland type; Rankabund $=$ Species abundance, Logsum= Logarithm with base 10 of species abundance; for species name abbreviation see the legend of Fig. 2 
L., Scabiosa columbaria L., Plantago lanceolata L., etc. The least frequent are: Rumex acetosa L., Veratrum album L., Taraxacum officinale Weber ex F.H.Wigg, Ajuga genevensis L., Luzula campestris L., Trifolium pratense L., etc. (Fig. 5).

In Nardus stricta L. grassland type the most abundant species in addition to dominant species are: Arnica montana L., Thymus pulegiodes L., Festuca rubra L., Carlina acaulis L., Lotus corniculatus L., Potentilla erecta L., etc. The less dominant are: Rumex acetosa L., Scorzonera rosea Waldst. et Kit., Alchemilla vulgaris L., Trifolium pratense L., Vicia cracca L., etc. (Fig. 6).

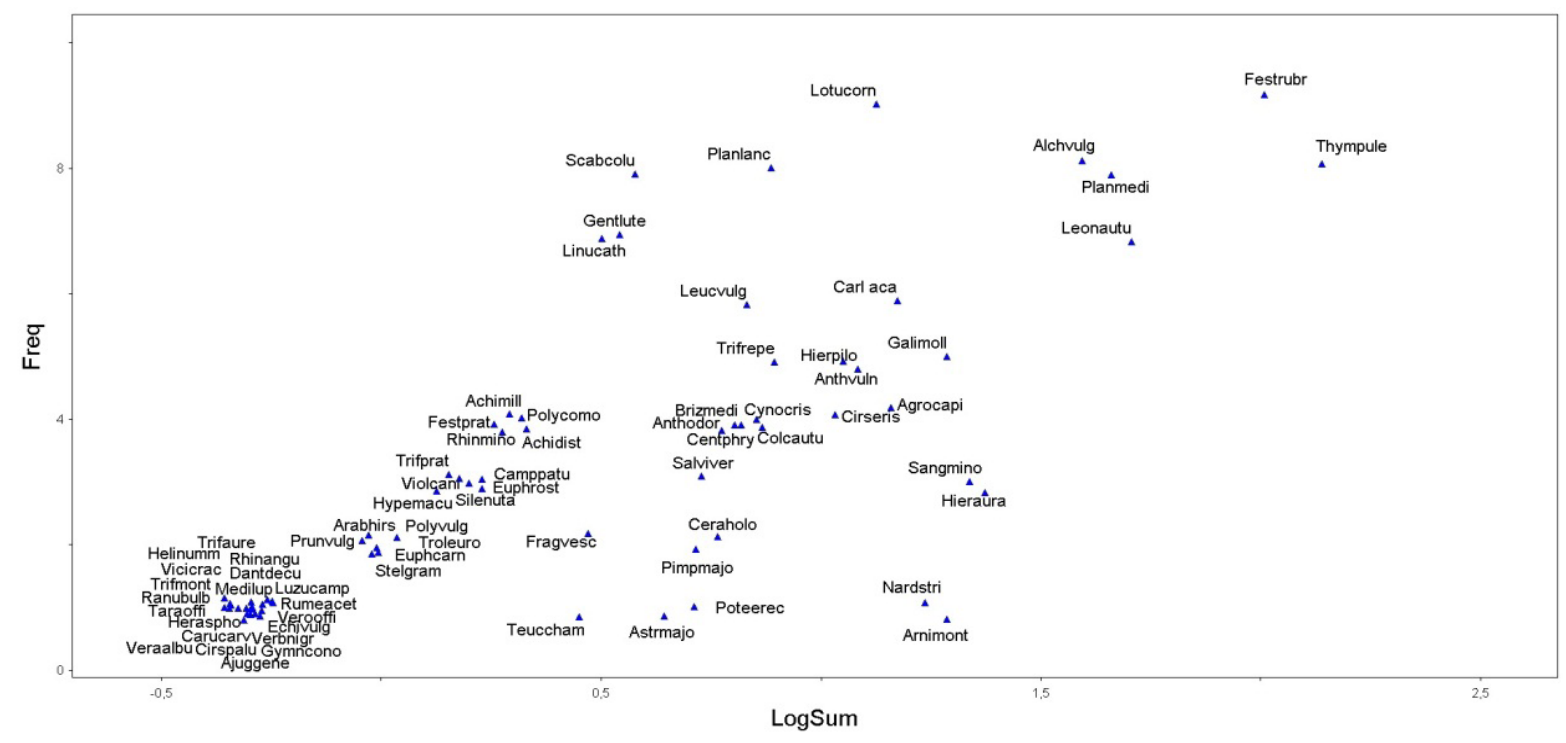

Fig. 5. Frequency of species in the phytocoenosis of Festuca rubra L. grassland type; Freq = Species frequency, Logsum = Logarithm with base 10 of species abundance; for species name abbreviation see the legend of Fig. 2

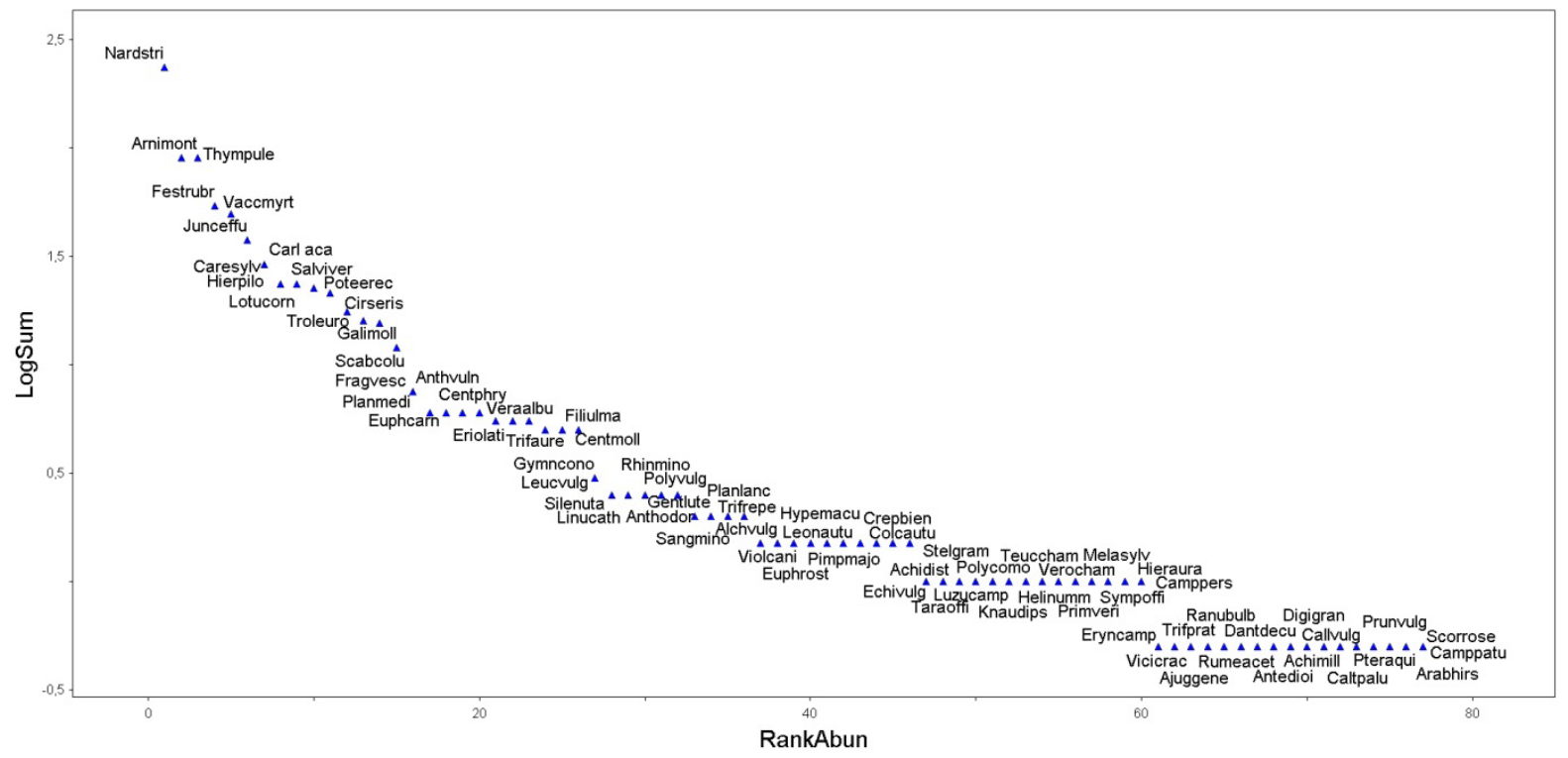

Fig. 6. Abundance of species in the phytocoenosis of Nardus stricta L. grassland type; Rankabund $=$ Species abundance, Logsum $=$ Logarithm with base 10 of species abundance; for species name abbreviation see the legend of Fig. 2 


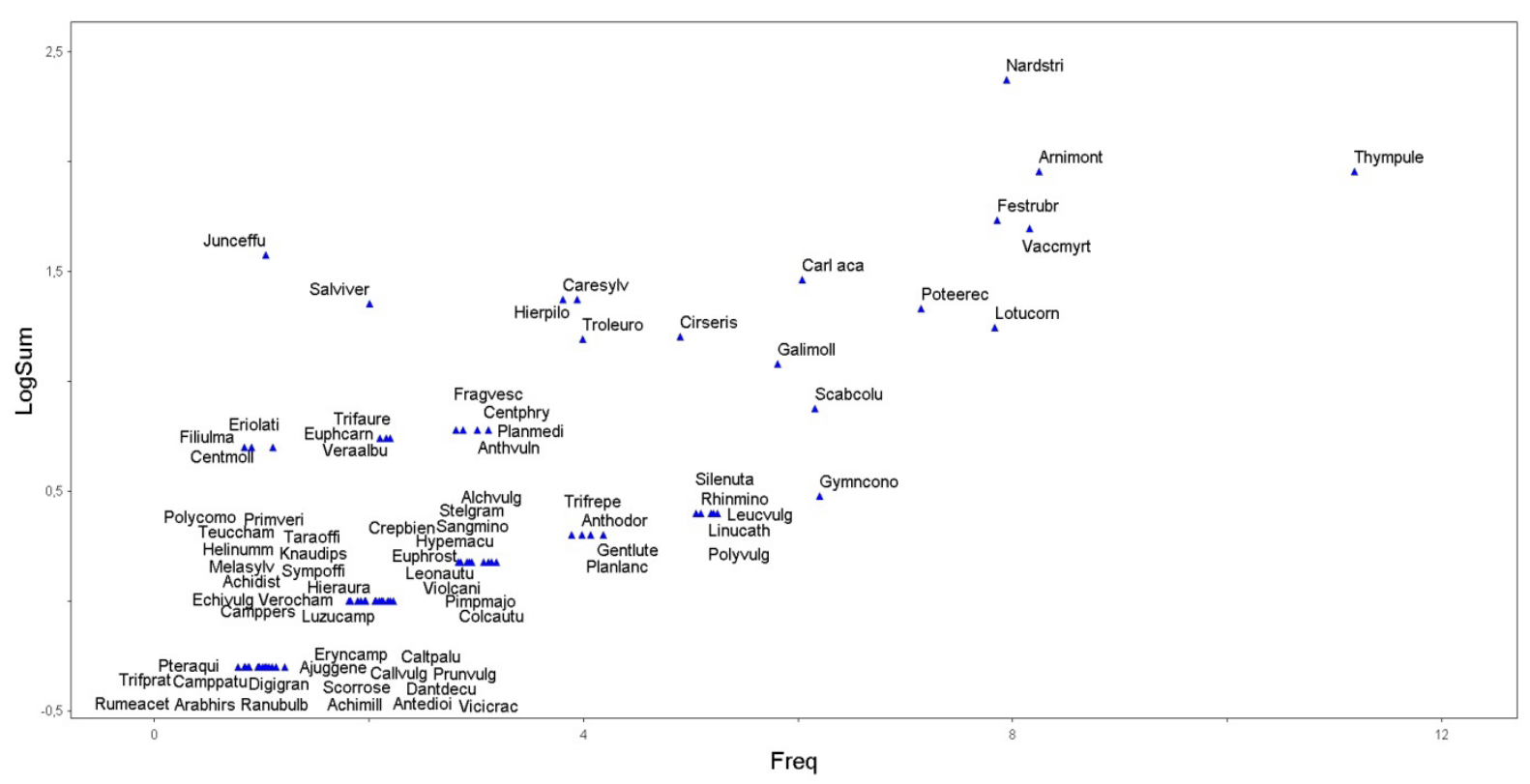

Fig. 7. Frequency of species in the phytocoenosis of Nardus stricta L. grassland type (Freq = Species frequency, Logsum = Logarithm with base 10 of species abundance, for the species name see the legend of Fig. 2)

The most frequent species are: Arnica montana L., Thymus pulegiodes L., Festuca rubra L., Potentilla erecta L., Lotus corniculatus L., Carlina acaulis L., etc. The least frequent are: Rumex acetosa L., Arabis hirsuta L., Ranunculus bulbosus L.; Eryngium campestre L., Scorzonera rosea Waldst. et Kit, Vicia cracca L., Antenaria dioica L., Alchemilla vulgaris L., Trifolium pratense L., etc. (Fig. 7).

\section{CONCLUSION}

The different categories of abandonment caused major changes in the floristic structure of phytocoenoses, determining the canopy's degradation both from agronomic and ecologic point of view. The major changes occur after 6 years of abandonment. The semi-natural grasslands, situated on sites with different disadvantages (defectuous orography, reduced trophicity, pronounced acidity, etc.) which are on the threshold to be abandoned or are already abandoned, need to be mowed at least once at four or five years, to preserve their specific floristic structure.

\section{REFERENCES}

1. Bilz M, Kell SP, Maxted N, Lansdown RV (2011). European Red List of Vascular Plants. Luxembourg: Publications Office of the European Union:130.

2. Da Ronch F, Macolino S, Ziliotto U (2010). Speed of reduction of the specific biodiversity in abandoned meadows when they are re-colonized by woodland. Grassland Science in Europe 15:678-680.

3. Da Ronch F, Pornaro C, Macolino S, Ziliotto U (2013) Effects of abandonment on some characteristics of mountain pastures. Grassland Science in Europe 18:457-459.

4. Fischer M, Wipf S (2002). Effect of low-intensity grazing on the species-rich vegetation of traditionally mown subalpine meadow. Biol. Conserv.104:1-111.

5. Galvanek D, Leps J (2012). The effect of management on productivity, litter accumulation and seedling recruitment in a Carpathian mountain grassland. Plant Ecol. 213(3):523-533.

6. Gârda N (2010). Studiul unor elemente de landșaft montan (cu privire specială asupra ecosistemelor de pajiști din comuna Gârda de Sus, Munții Apuseni), UASMV Cluj-Napoca, Phd. Thesys:270

7. Habel JC, Dengler J, Janiskova M, Torok P, Wellstein C, Wiezik M (2013). European grassland ecosystems: threatened hotspots of biodiversity. Biodivers. Conserv 22:2131-2138.

8. Halada L, Evans D, Romao C, Petersen JE (2011). Which habitats of European importance depend on agricultural practices? Biodivers Conserv. 20:2365-2378. 
9. Kącki Z (2010). Differences in plant species diversity between managed and abandoned semi-natural meadows. Grassland Science in Europe 15:808-811.

10. Kahmen S, Poschlod P, Schreiber K (2002). Conservation management of calcareous grasslands. Changes in plant species composition and response of functional traits during 25 years. Biol. Cons. 104(3):319-328.

11. Kryszak A, Kryszak J, Strychalska A, Klarzynska A (2012). The effect of utilization on the floristic composition of meadow communities. Journal of Life Sciences 6:10611067.

12. Marriott C, Fothergill M, Jeangros B, Scotton M, Louault F (2004). Long-term impacts of extensification of grassland management on biodiversity and productivity in upland areas. Agronomie 24:447-462.

13. McCune B, Grace JB (2002). Nonmetric Multidimensional Scaling. In: Analysis of ecological communities. MJM Software Design, United States of America:188-198.

14. Musiał K, Kasperczyk M (2013). Changes in floristic composition of the mountain pasture sward after the abandonment of sheep grazing. Grassland Science in Europe 18:418-420.

15. Osterburg B, Isermeyer F, Lassen B, Röder N (2010). Impact of economic and political drivers on grassland use in the EU. Grassland Science in Europe 15:14-28.
16. Peck JE (2010). Multivariate Analysis for Community Ecologists: Step - by - Step using PC - ORD. MjM Software Design, Gleneden Beach, OR:162.

17. Schrautzer J, Jensen K, Breuer V, Breuer M (2010). Longterm effects of large-scale, moderate grazing on the vegetation of a river valley. Grassland Science in Europe 15:848-850.

18. Socher SA, Prati D, Boch S, Müller J, Baumbach H, Gockel S, Hemp A, Schöning I, Wells K, Buscot F, Kalko EKV, Linsenmair KE, Schulze ED, Weisser WW, Fischer M (2013). Interacting effects of fertilization, mowing and grazing on plant species diversity of 1500 grasslands in Germany differ between regions. Basic and Applied Ecology 14:126-136.

19. Vîntu V, Samuil C, Rotar I, Moisuc A, Razec I (2011). Influence of the management on the phytocoenotic biodiversity of some Romanian representative grassland types. Not Bot Hort Agrobot Cluj 39(1):119-125.

20. Vîntu V, Samuil C, Sîrbu C, Popovici C, Stavarache M (2011). Sustainable management of Nardus stricta L. grasslands. Not Bot Horti Agrobo. 39(2):142-145.

21. Zarzycki J, Misztal A (2010). Abandonment of farming practices: impact on vegetation. Grassland Science in Europe 15:133-135.

22. ***STATSOFT INC. 2012. Electronic Statistics Textbook. Tulsa, OK: StatSoft. WEB: http://www.statsoft.com/ textbook/ 